UCLA - $12 \cdot 852$

\title{
UNIVERSITY OF CALIFORNIA, LOS ANGELES
}

RECEIVED BY. DTIE DEG 221971

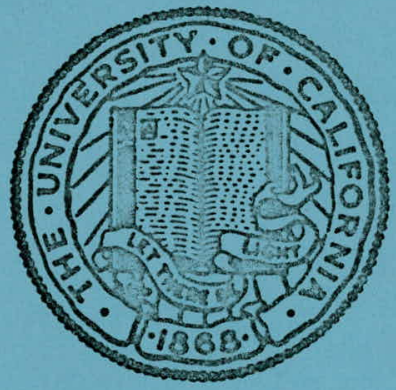

LABORATORY OF NUCLEAR MEDICINE AND RADIATION BIOLOGY CONTRACT NO. AT (04-1) GEN-12 


\section{DISCLAIMER}

This report was prepared as an account of work sponsored by an agency of the United States Government. Neither the United States Government nor any agency Thereof, nor any of their employees, makes any warranty, express or implied, or assumes any legal liability or responsibility for the accuracy, completeness, or usefulness of any information, apparatus, product, or process disclosed, or represents that its use would not infringe privately owned rights. Reference herein to any specific commercial product, process, or service by trade name, trademark, manufacturer, or otherwise does not necessarily constitute or imply its endorsement, recommendation, or favoring by the United States Government or any agency thereof. The views and opinions of authors expressed herein do not necessarily state or reflect those of the United States Government or any agency thereof. 


\section{DISCLAIMER}

Portions of this document may be illegible in electronic image products. Images are produced from the best available original document. 
POSTURAL INFLUENCE ON LOBAR DISTRIBUTION OF BLOOD FLOW IN DOGS

NORMAN D. POE

(INTRODUCED BY GEORGE V. TAPLIN)

THE DEPARTMENT OF RADIOLOGICAL SCIENCES

UCLA SCHOOL OF MEDICINE, LOS ANGELES, CALIFORNIA 90024

AND THE LABORATORY OF NUCLEAR MEDICINE AND RADIATION BIOLOGY

900 VETERAN AVENUE

UNIVERSITY OF CALIFORNIA, LOS ANGELES, CALIFORNIA 90024

Running title: Postural Influence on Lobar Blood Flow

* This project was supported in part by Contract At $(04-1)$ GEN-12 between the United States Atomic Energy Commission and the University of California at Los Angeles. 
Over the last two decades, a number of experimental and clinical reports have confirmed a gravitational effect on the distribution of pul-. monary arterial blood flow which favors the dependent regions of the lungs. Verification has been provided by a variety of techniques including lobar gas analysis, implanted flow meters and external monitoring of inhaled radioactive gas $(1-3)$. Regional flow patterns have also been obtained with radioactive particles using scintiscanning (4).

In spite of important generic differences between man and dog, the latter is commonly chosen as the experimental model for pulmonary and cardiovascular studies. This creates the need for defining and quantitating as many of the existing hemodynamic variables as possible. Measurements of postural effects on flov through individual lobes have been limited or inconclusive $(2,5,6)$. To clarify these effects and to establish a set of normal values for dogs under usual laboratory conditions, postural influence on the lobar distribution of intravenousiy injected radioiodinated, macroaggregated albunin (MAA) was determined.

\section{MATERIAIS AND METHODS}

Twenty-one mediurn to large mongrel dogs, average weight $20 \mathrm{~kg}$, were selected. Fourteen had some characteristics identifiable as German Shepherd. Light anesthesia was obtained by intravenous pentobarbital, - approximately $25-30 \mathrm{mg} / \mathrm{kg}$, with the animal prone. Five minutes prior to - tracer injection the animal was placed in the desired posture, i.e., right or left lateral recumbent, upright or inverted position ${ }^{2}$ or was kept prone an equivalent period of time for the prone studies. A slow injection of 
specially prepared iodine-131 labeled $\mathrm{MAA}$ (100 $\mu \mathrm{Ci} / 3.5 \mathrm{mg}$ albunin, size range 10-90.microns maxinum diameter) bas made into a leg vein. Two minutes after completion of the injection, the animal vas returned to the prone position for five minutes, then sacrificed with a large dose of intravenous potassium chloride. The lungs were immediately removed and blotted $\mathrm{dry}$. The lobes vere isolated, weighed, diced, then counted in a large wंe 11 counter.

\section{RESULT'S}

The results of postural effects of lobar flow in lightly anesthetized dogs are found in Table I. Values are expressed as "percent flor" (percent of total lung activity in each lobe) and "relative flow per gram" (the ratio of activity per lobe to lobe weight divided by the ratio of total lung activity to total lung weight). The latter figure allows for comparisons of relative flow independent of tissue mass. Table II gives the veight distribution of the seven lobes.

TABLE I

In the prone, upright, and inverted positions in wich the two lungs maintain the same relative relationship, the flows correlate almost perfectly with the weights. In all positions a gravitational effect is seen. In the prone position the large superiorly placed diaphragmatic lobes have the greatest total flow but the least flow per gram. With the animal upright the apical flow falls to less than $7 \%$ of the total flow although these lobes account for approximately $25 \%$ of the lung mass. In contrast, with the animal inverted, a ruch smaller decrease in flow is observed in the nondependent diaphragmatic lobes. This minimal change 
is probably due in part to an increased cardiac output secondary to the greatly increased respiratory effort encountered in this posture. In the lateral positions, flow changes tend to increase in the dependent lobes and to decrease in the nondependent lobes. Less change is noted in the intermediate lobe which receives its arterial supply from the right main pulmonary artery but which lies partially in the left chest cavity.

The mean weight for the 21 dogs was $20.0 \pm 3.6 \mathrm{~kg}$ (range 29-6i) with lung wet weight of $139.8+31.6$ gin (range 77-205). These values yicld an avcrage of $0.70 \mathrm{gm}$ lung weight per $100 \mathrm{gm}$ body weight.

\section{DISC.USSION}

The results of this study show a definite postural effect on the distribution of pulmonary arterial blood flow in the dog which favors the dependent lobes. Both the theory and the reliability of measuring regional flov with radioactive particles have been established for litA and for plastic microspheres $(7,8)$. The major limitation of this method is the need for obtaining tissue counts for flow quantitation in anatornic subdivisions of the lung. However, external counting or scintiscianning can be used to provide estimates of regional flow changes in vivo. Microsphcres, because of greater control in particle size and of a more even distribution of radioactivity, may be preferred rinen precise measurements are required. Likewise, IAAA may be advantageous for repeat experiments because they do not permanently block the arteriolar-capillary bed. Microspheres made from albumin nay be superior to either INA or plastic microspheres by retaining the desirable characteristics of both (7). 
Changes in body posture can cause alterations in cardiac output (2). c. This parameter was not measured in this study and is not nomally taken into consideration in experiments where a single posture is maintained. However, conditions or drugs which increase cardiac output or raise pulmonary arterial pressure have beein shown to reduce the gravitational effect (9). The reverse is true when output or pressure are lonered.

A set of normal values for lung and lobar welghts in dogs is established. The mean value of $0.70 \mathrm{gm}$ lung per $100 \mathrm{gm}$ body weight is somewhat lover than that which has previously appeared in literature $(10,11)$, but the relative percent of weight by lobes agrees closely with published measurements (5).

It is concluded that body posture has an important influence on relative flow of blood to the various lobes in canine lungs and these differences must be taken into consideration in many pulmonary and circulatory expariments in wich dogs are utilized.

\section{SUMATRY}

A study bas undertaken in dogs to determine the role of posture on regional pulmonary arterial perfusion and to establish a set of normal values for lobar blood flow in various body positions. Relative flow through each of the seven lobes was measured by in vitro tissue counting in five body positions following intravenous injection of albumin macroaggregates. In each position a definite flow gradient was found which favored the dependent lobes. Quantitative results are presented as are values for lung and lobar weights. 


\section{REFERENCES}

1. Svanberg, L., Scand. J. Clin. Lab. Invest., 9, 1, Supp1. 25 (1957).

2. Guntheroth, W.G., Morgan, B.C., and Lintermans, J.P., J. Appl. Physiol., 23, 859 (1967).

3. Kaneko, K., Milic-Emilj, J., Dolovich, M.B., and Bates, D.V., J. Appl. Physiol., 21, 767 (1966).

4. Isawa, T., Okubo, K., and Oka, S., Tohoku J. Exp. Ked. 94, 315 (1968).

5. Rahn, H., Sadoul, P., Fahri, I.E., and Shapiro, J., J. Appl. Physiol. 8,417 (i956).

6. Hamlin, R.L., Marsland, H.P., Smith, C.R., and Sapirstein, I.A., Circulat. Res. 10, 763 (1962).

7. Vagner, H.N., Jr., Rhodes, B.A., Sasaki, Y., and Ryan, J.P.: Invest. Radjol. 4,374 (1969).

8. Rudolph, A.M. and Heymann, M.A., Circulat. Res. 21, 163 (1967).

9. Poe, N.D., Swanson, L.A., and Taplin, G.V., Radiology 80, 661 (1967).

10. Quiring, D.F., "Functional Anatony of the Vertebrates", p. 545, McGrav-Hi11, New York (1950).

11. Spector, H.D. (ed.); "Handbook of Biological Data", p. 163, W.B. Saunders, Philadelphia (1956): 
FOOTNOTES

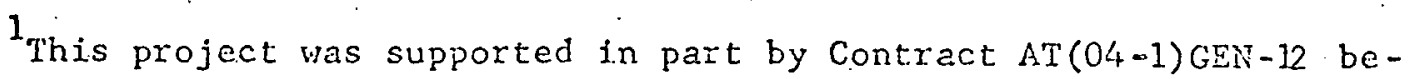
tween:the United States Atomic Energy Comnission and the University of California at Los Angeles.

2 The inverted posture was not maintained for a full five minutes as the animals were hand held. In addition, in this position they invariably developed respiratory distress and were not in a basal state. 
TABLE 1

Postural Influence on the Distr!butlon of Pulmonary Arterlal Blood Fow Determined Irom Exclsed Tissue

\begin{tabular}{|c|c|c|c|c|c|c|c|c|c|c|c|c|}
\hline & \multirow[b]{2}{*}{ Lobe } & \multicolumn{2}{|c|}{ Drone } & \multicolumn{2}{|c|}{ Upright } & \multicolumn{2}{|c|}{ Inverted } & \multicolumn{2}{|c|}{ Right Lateral } & \multicolumn{3}{|c|}{ Left Latera! } \\
\hline & & $\begin{array}{l}\text { Relative } \\
\text { Flow/Gram }\end{array}$ & $\begin{array}{l}\text { Percent } \\
\text { Flow }\end{array}$ & $\begin{array}{l}\text { Relatlve } \\
\text { Flow/Gram }\end{array}$ & $\begin{array}{c}\text { Percent } \\
\text { F!ow }\end{array}$ & $\begin{array}{c}\text { Relative } \\
\text { Flow/Gram }\end{array}$ & $\begin{array}{l}\text { Percent } \\
\text { Flow }\end{array}$ & $\begin{array}{l}\text { Relative } \\
\text { Flow/Gram }\end{array}$ & $\begin{array}{l}\text { Percent } \\
\text { Flow }\end{array}$ & & $\begin{array}{l}\text { Relative } \\
\text { Flow/Gram }\end{array}$ & $\begin{array}{l}\text { Percent } \\
\text { Flow }\end{array}$ \\
\hline \multirow{4}{*}{ RGHT LUNC } & $\begin{array}{l}\text { Aplcal } \\
\text { Menn } \\
\text { Range }\end{array}$ & $\begin{array}{l}1.12 \\
1.02-1.24\end{array}$ & $\begin{array}{c}18.6 \\
17.0-21,8\end{array}$ & $\begin{array}{c}0.28 \\
0.08-0.50\end{array}$ & $\begin{array}{c}4.3 \\
1.4-8.4\end{array}$ & $\begin{array}{c}1.48 \\
1.10-2.05\end{array}$ & $\begin{array}{c}24.5 \\
20.1-30.7\end{array}$ & $\begin{array}{c}1.00 \\
0.76-1.03\end{array}$ & $\begin{array}{c}18.0 \\
14.4-23 . \varepsilon\end{array}$ & & $\begin{array}{c}0.72 \\
0.39-0.88\end{array}$ & $5.3-74.6$ \\
\hline & $\begin{array}{l}\text { Cardiac } \\
\text { Mean } \\
\text { Range }\end{array}$ & $1.12-1.70$ & $\begin{array}{c}11.4 \\
10.5-12.4\end{array}$ & $\begin{array}{c}0.85 \\
0.72-1.01\end{array}$ & 5. $\stackrel{7-9.2}{9.2}$ & $\begin{array}{c}1.08 \\
0.05-1.22\end{array}$ & 8. ${ }^{9.6}-11.5$ & $\begin{array}{c}1.26 \\
0.75-1.67\end{array}$ & 7. $\begin{array}{l}11.3 \\
4-13.6\end{array}$ & & $\begin{array}{c}0.59 \\
0.39-0.77\end{array}$ & $\begin{array}{c}4.9 \\
3.6-6.8\end{array}$ \\
\hline & $\begin{array}{l}\text { D!aphragmatie } \\
\text { Mcoun } \\
\text { Pange }\end{array}$ & $\begin{array}{c}0.77 \\
0.72-0.82\end{array}$ & $\begin{array}{c}18.4 \\
17.8-19.3\end{array}$ & $\begin{array}{c}1.52 \\
1.11-1.89\end{array}$ & $\begin{array}{c}37.2 \\
30.4-46.9\end{array}$ & $\begin{array}{c}0.70 \\
0.49-1.00\end{array}$ & $\begin{array}{c}17.8 \\
12.9-25.2\end{array}$ & $\begin{array}{c}1.21 \\
0.94-1.30\end{array}$ & $\begin{array}{c}28.9 \\
24.4-32.8\end{array}$ & & $\begin{array}{c}0.72 \\
0.56-0.83\end{array}$ & $\begin{array}{l}17.7 \\
15.0-21.5\end{array}$ \\
\hline & $\begin{array}{l}\text { Intermediate } \\
\text { Wean } \\
\text { Ringe } \\
\text {. }\end{array}$ & $\begin{array}{l}1.19 \\
1.03-1.40\end{array}$ & 8. ${ }^{10.3} .13 .1$ & $\begin{array}{c}1.28 \\
1.09-1.41\end{array}$ & 8. $3=12.2$ & $\begin{array}{c}0.73 \\
0.50-0.92\end{array}$ & $\begin{array}{c}8.8 \\
4.9-8.3\end{array}$ & $\begin{array}{c}1.08 \\
0.84-1.26\end{array}$ & $\begin{array}{c}8.4 \\
\text { 7. } 9-8.9\end{array}$ & & $\begin{array}{c}1.14 \\
0.99-1.24\end{array}$ & $\begin{array}{c}8.8 \\
8.3^{3.9 .7}\end{array}$ \\
\hline \multirow{6}{*}{ LEFT LUNC } & $\begin{array}{l}\text { Total } \\
\text { Mcan } \\
\text { Range }\end{array}$ & $\begin{array}{l}1.02 \\
0.94-1.10\end{array}$ & $\begin{array}{c}58.7 \\
53.9-62.2\end{array}$ & {$\left[\begin{array}{c}1.01 \\
0.92-1.05\end{array}\right.$} & $\begin{array}{c}58.8 \\
55.0-61.7\end{array}$ & $\begin{array}{c}0.99 \\
0.97-1.03\end{array}$ & $\begin{array}{c}58.7 \\
57.5-00.4\end{array}$ & $\begin{array}{c}1.12 \\
1.01-1.29\end{array}$ & $\begin{array}{c}69.5 \\
62.9-75.4\end{array}$ & & $\begin{array}{c}0.76 \\
0.58-0.85\end{array}$ & $\begin{array}{c}43.0 \\
33.6-48.9\end{array}$ \\
\hline & . & & & & & & & $:$ & & & & \\
\hline & $\begin{array}{l}\text { Ap!cal } \\
\text { Mean } \\
\text { Range }\end{array}$ & $\frac{1.04}{0.94-1.14}$ & 8. $\begin{array}{c}10.6 \\
9-12.4\end{array}$ & $\begin{array}{c}0.22 \\
0.07-0.44\end{array}$ & $0.0-2^{2} .8$ & 1. $17-1.92$ & $12.8-18.3$ & $\begin{array}{c}0.85 \\
0.70-0.98\end{array}$ & $7.7^{8.0} \cdot{ }^{8} .3$ & & $\begin{array}{c}1.05 \\
1.04-1.07\end{array}$ & $\begin{array}{c}10.3 \\
8.6-12.2\end{array}$ \\
\hline & $\begin{array}{l}\text { Cardiac } \\
\text { Me:In } \\
\text { rim!: }\end{array}$ & $1.31-1.71$ & $\begin{array}{c}8.3 \\
7.4-9.5\end{array}$ & $\begin{array}{c}0.68 \\
0.26-0.94\end{array}$ & $1.8-7.8$ & $\begin{array}{c}1.32 \\
1.09-1.73\end{array}$ & 5. $\begin{array}{c}7.0 \\
8-7.0\end{array}$ & $\begin{array}{c}0.75 \\
0.62-0.85\end{array}$ & $3.5-5.5$ & & $\begin{array}{c}1.38 \\
1.16-1.86\end{array}$ & $\begin{array}{c}6.7 \\
5.77 .7 .0\end{array}$ \\
\hline & $\begin{array}{l}\text { Diaphragmatic } \\
\text { Nean } \\
\text { Raunge }\end{array}$ & $\begin{array}{c}0.85 \\
0.64-0.95\end{array}$ & 17. 22.4 & 1. $13-1.37$ & $\begin{array}{c}34.7 \\
31.4-38.3\end{array}$ & $\begin{array}{c}0.80 \\
0.60-0.90\end{array}$ & $\begin{array}{l}20.2 \\
10.7-22.2\end{array}$ & $\begin{array}{c}0.84 \\
0.54-0.99\end{array}$ & $\begin{array}{c}20.8 \\
13.1-24.1\end{array}$ & . & $1.28-1.68$ & $33.9 .9-51.0$ \\
\hline & $\begin{array}{l}\text { Tolal } \\
\text { Mean } \\
\text { Ranfge }\end{array}$ & $\begin{array}{c}0.98 \\
0.88-1.08\end{array}$ & $\begin{array}{c}41.3 \\
37.8-49.1\end{array}$ & $\begin{array}{c}0.99 \\
0.93-1.12\end{array}$ & 38.3 .45 .0 & $\begin{array}{c}1.01 \\
0.96-1: 05\end{array}$ & $\begin{array}{c}41.3 \\
39.6-42.5\end{array}$ & $\begin{array}{c}0.82 \\
0.59-0.83\end{array}$ & $\begin{array}{c}33.5 \\
24.6-37.1\end{array}$ &. & $1.20-1.57$ & $\begin{array}{l}57.0 \\
51.0-60.4\end{array}$ \\
\hline
\end{tabular}

* Flve dogs In the Prone group and four each in the remaining groups 
TABLT I

Weleht by Dorcent O! Inddv!dual Lobes A S.D. (Rnngo)

\begin{tabular}{|c|c|c|c|c|c|c|c|c|}
\hline \multicolumn{5}{|c|}{ RIGYT LUNG } & \multicolumn{4}{|c|}{ LEFT LUNG } \\
\hline Aplea! & Cardiac & Dlaphragmatlc & Intermediate & Total & Ap!en! & Cardiac & Dlaphrasmatic & Totnd \\
\hline$\cdot$ & & & & & & & & \\
\hline $10.7 \$ 1.6$ & $0.0 \$ 1.0$ & $24.3+1.0$ & 8. 381.1 & $58.9 \$ 1.8$ & $0.0 \pm 1.0$ & $5.8 \pm 0.9$ & 28. $1 \pm 1.7$ & $41.7 \pm 16$ \\
\hline$(19.8-20.5)$ & & & & $(55.6-61.1)$ & $(0.3+11.7)$ & $(3,7-7.3)$ & $(23.1-30.3)$ & $(33.3-14.6)$ \\
\hline
\end{tabular}


